\title{
Bimbingan Penerimaan Diri Remaja Broken Home
} Fahrurrazi Fahrurrazi* ${ }^{*}$, Casmini Casmini ${ }^{2}$

1,2Program Studi Bimbingan dan Konseling Islam, Universitas Islam Negeri (UIN) Sunan

Kalijaga, Yogyakarta, Indonesia.

*11 Corresponding author, ఏe-mail: fahrurrazi824@gmail.com

$\begin{array}{ccc}\text { Received: } & \text { Accepted: } & \text { Published: } \\ \text { 11 June 2020 } & 03 \text { November 2020 } & \text { 29 December 2020 }\end{array}$

\begin{abstract}
This study aims to determine the process of experience that makes the subject re-accept himself and the guidance obtained by the subject so that he is able to accept himself again. This research is a phenomenological qualitative study with a single informant who does experience broken home families. Data collection was carried out by interview and observation. Data analysis techniques used data reduction, data presentation and drawing conclusions. The results of this study indicate that the process of experience gained through pre-broken home, during broken home, and post-broken home. Meanwhile, the guidance obtained by the subject comes from his grandfather and lover. The implication of the results of this study is to analyze need assessment of the guidance and counseling program for the implementation of family counseling in families experiencing broken homes.
\end{abstract}

Keywords: Self Acceptance, Broken Home, Teenagers, Family Counseling

\begin{abstract}
Abstrak
Kajian ini bertujuan untuk mengetahui proses pengalaman yang membuat subyek kembali menerima dirinya sendiri serta bimbingan-bimbingan yang didapatkan oleh subjek sehingga mampu menerima dirinya lagi. Kajian menggunakan metode kualitatif bersifat fenomenologis dengan informan tunggal yang memang benar-benar mengalami keluarga broken home. Pengumpulan data dilakukan dengan wawancara dan observasi. Teknik analisis data menggunakan reduksi data, penyajian data dan penarikan kesimpulan. Hasil penelitian ini menunjukkan bahwa proses pengalaman yang didapatkan melalui pra-broken home, saat broken home, dan pasca-broken home. Sedangkan bimbingan yang didapatkan oleh subyek berasal dari keluarga. Impilkasi hasil penelitian ini terhadap analisis kebutuhan program bimbingan dan konseling pelaksanaan konseling keluarga pada keluarga yang mengalami broken home.
\end{abstract}

Kata Kunci: Penerimaan Diri, Broken Home, Remaja, Konseling Keluarga

How to Cite: Fahrurrazi, F., \& Casmini, C. (2020). Bimbingan Penerimaan Diri Remaja Broken Home. ENLIGHTEN: Jurnal Bimbingan Konseling Islam, 3(2), 142-152.

https://doi.org/10.32505/enlighten.v3i2.1582

\section{PENDAHULUAN}

Kajian tentang remaja, merupakan memberontak, kebingungan (Khamim, suatu hal yang tidak pernah habis untuk 2017), serta memiliki emosional yang tinggi didiskusikan. Remaja merupakan (Sarlito Sarwono, 2013). Pada umumnya, peralihan umur dari usia anak-anak hingga usia remaja berkisar antara 12-21 tahun ke usia dewasa, yangkerap menunjukkan (King A. Laura, 2013). Lebih spesifiknya perilaku-perilaku tertentu seperti gelisah, lagi, masa remaja berlangsung antara usia 
12-21 tahun bagi perempuan dan 13-22 bagi laki-laki. Rentang usia tersebut dibagi menjadi dua bagian, yaitu 12/13 tahun sampai 17/18 tahun disebut sebagai remaja awal. Sedangkan 17/18 tahun sampai 21/22 tahun disebut sebagai remaja akhir (Fallis, 2017). Ketika menginjak masanya, remaja telah meninggalkan masa kekanakkanakannya yang memiliki sifat manja dan penuh ketergantungan kepada orang lain, namun ia belum mampu bertanggung jawab atas segala tindakan baik terhadap dirinya sendiri maupun orang sekelilingnya (Willis, 2009). Dalam proses tumbuh kembang remaja cenderung tidak bahagia disebabkan oleh banyaknya masalah yang dihadapi meskipun dalam sisi lain remaja juga memiliki kebahagiaan (Hafiza \& Mawarpury, 2018). Oleh sebab itu tidak semua remaja sama. Keberagaman etnis, budaya, gender, gaya hidup, sejarah, dan sosial-ekonomi yang menyebabkan pengalaman hidup mereka berbeda-beda (King A. Laura, 2013).

Masa remaja merupakan masa yang sangat penting untuk mengembangkan segala potensi yang dimiliki, seperti bakat, minat, dan norma-norma kehidupan. Namun di sisi lain, tidak begitu sedikit remaja yang melalaikan waktunya untuk melakukan hal-hal yang berkonotasi positif, yang ada justru remaja melakukan hal-hal negatif, seperti keluar dari rumah, tawuran, balapan liar, merokok, hingga mengkonsumsi narkoba (Ningrum, 2013). Pada masa remaja seseorang akan mudah merasa takut, khawatir, atau bahkan gelisah, terutama saat dihadapkan pada suatu problem (Batubara, 2016). Salah satu contoh problematika tersebut adalah broken home.

Broken home merupakan suatu keadaan (perceraian) yang terjadi karena tidak adanya keharmonisan dalam rumah tangga baik antara suami-istri maupun anak (Hadyani \& Indriana, 2017). Yang menjadi faktor penyebab kerap terjadinya broken home adalah putusnya hubungan (pernikahan) antara ibu dan bapak disebabkan karena kematian dan perceraian (Pratama et al., 2016). Kurangnya perhatian dan kasih sayang dari orang tua membuat mental anak menjadi lemah sehingga memiliki efek yang sangat besar terhadap mental atau kejiwaan seorang remaja. Konsep diri pada remaja yang mengalami broken home tentu saja berbeda dengan remaja pada umumnya karena mereka mengalami situasi dan keadaan yang tidak sama (Wulan Dwiyanti Rahayu \& Mila Fatimah, 2019). Remaja broken home lebih banyak mengalami masalah dibandingkan dengan remaja yang keluarganya harmonis (Victor Omoruyi, 2014). Salah satu faktor penyebab rendahnya potensi remaja dalam menyelesaikan masalah yang berdampak pada munculnya kenakalan remaja dan berbagai permasalahan adalah akibat hubungan keluarga yang tidak baik, sehingga orang tua sendiri lemah dalam melakukan pengawasan terhadap anakanaknya (Rahmawati, 2015). Remaja yang mengalami broken home lebih rentan memiliki perasaan emosi, kecewa, tertekan, malu, bahkan sakit hati selama dalam proses perceraian orang tuanya, yang akan menyalurkan ekspresinya dengan cara menunjukkan sikap ketidaksukaan 
terhadap pihak yang menimbulkan perceraian orang tuanya (Safitri, 2017; Triyono, 2020).

Di Indonesia, jumlah keseluruhan dari kasus perceraian sebagaimana yang terakhir dilansir oleh Badan Pusat Statistik (BPS) pada tahun 2017 adalah sebanyak 374.516 kasus perceraian (Iis Islami Kartini et al., 2019). Di daerah istimewa Yogyakarta sendiri, tingkat perceraian setiap tahunnya selalu meningkat. Namun pada tahun 2016 sedikit mengalami penurunan. Sebagaimana yang terdapat dalam data yang telah dipublikasikan oleh Badan Pusat Statistik, bahwa jumlah kasus perceraian yang terjadi di Yogyakarta pada tahun 2016 adalah sebanyak 5.161 kasus perceraian, berbeda dengan tahun 2012 yang memiliki jumlah kasus perceraian terbanyak yaitu 5.441 kasus.

Research yang telah dilakukan oleh Sarbini dan Kusuma (2014) mengenai kondisi psikologis remaja dalam keluarga yang bercerai menjelaskan bahwa dampak yang dirasakan oleh anak korban perceraian orang tuanya antara lain: merasa tidak aman, adanya rasa penolakan dari keluarga, marah, sedih, kesepian, dan perasaan menyalahkan diri sendiri (Wulandri \& Fauziah, 2019). Dikuatkan lagi oleh temuannya (Aziz, 2015) di Kota Banda Aceh menunjukkan bahwa remaja dengan keluarga broken home memiliki perilaku-perilaku yang menyimpang, seperti tidak sopan, tidak mengerjakan tugas sekolah, tidak memiliki motivasi untuk belajar, dan suka mencari perhatian dari orang lain. Jadi, dapat disimpulkan bahwa penelitian-penelitian sebelumnya yang membahas tentang dampak psikologis remaja yang mengalami broken home cenderung memiliki sikap negatif dan tidak menunjukkan perubahan sikap yang signifikan.

Dalam teorinya Kubler Ross tentang kedukaan (griefing), bahwa ada lima tahap yang dialami oleh seseorang, mulai dari tahap penolakan sampai kepada penerimaan diri (Yunita \& Lestari, 2018). Penerimaan diri adalah awal dari pembentukan kepribadian yang positif terhadap seseorang agar mampu memahami dirinya sendiri serta mengenal dan menerima orang lain (Wulan Dwiyanti Rahayu \& Mila Fatimah, 2019). Serta menjadi hal yang sangat penting bagi kesehatan mental seseorang (Untari et al., 2018), yang terkait dengan depresi dan kecemasan (Jhon M. Chamberlain \& David A. F. Haaga, 2001). Remaja yang sadar akan kelebihan dan kekurangan pasti akan menerima dirinya sendiri serta memiliki keperibadian yang baik jika mendapatkan dukungan dari keluarga dan lingkungan terdekat (Putri \& Tobing, 2016). Perceraian orang tua juga menjadi faktor utama remaja sulit menerima keadannya sendiri (Hadyani \& Indriana, 2017).

Selama ini, sikap negatif remaja broken home menggambarkan bahwa dirinya belum mampu menerima keadaannya secara utuh. Hal ini dibuktikan dengan informasi yang di dapatkan peneliti bahwa subyek sering curhat akan masalah yang sedang dihadapinya. Oleh karena itu, fokus kajian dalam penelitian ini adalah bagaimana suatu proses pengalaman yang membuat remaja broken home kembali menerima dirinya sendiri serta bimbingan yang Enlighten: Jurnal Bimbingan Konseling Islam $₫$ Vol 3 No 2 
didapatkan untuk bisa menerima dirinya sendiri lagi.

\section{METODE}

Penelitian ini menggunakan metode kualitatif yang bersifat fenomenologis. Fenomenologis merupakan suatu metode yang bertujuan mendiskripsikan, mengkaji, serta memahami suatu kejadian yang dialami oleh seseorang, berupa perubahan sikap maupun perilaku orang yang merasakan kejadian tersebut(Jhon W. Creswell, 2019). Dalam konteks ini remaja broken home.

Sebagai informan tunggal yang mengalami broken home, dengan kesepakatan mencantumkan inisial nama dalam penelitian. Penelitian ini dilakukan sangat mendalam dan komprehensip yang didapatkan berkaitan dengan self acceptance. Mulai dari pengalaman informan pra-broken home, saat broken home, dan pasca broke home. Sehingga nanti bisa dilihat kapan informan menerima bimbingan itu, apakah ketika proses broken home atau pasca broken home. Satu orang ini memang yang benar-benar mengalami dan berkaitan dengan ketersedian subjek untuk digali datanya secara mendalam dengan kesepakatan mencantumkan inisial nama di penelitian. Subjek mengalami broken home selama dua tahun, hal ini menarik untuk diteliti dari sepanjang itu, meskipun dari proses yg panjang tapi subjek bisa bangkit dari keterpurukannya.

Data diperoleh melalui wawancara mendalam secara face to face kepada subjek, yang dilakukan secara natural atau terstruktur untuk menjaga kenyamanaan dan kerahasian nama subjek. Hal yang diwawancarai dengan subjek berkaitan dengan pengalaman pra-broken home, saat broken home, dan pasca-broken home. Sedangkan observasi dilakukan untuk mengamati perilaku-perilaku subjek tanpa sepengetahuan subjek.

Dalam penelitian ini, ada beberapa tahapan yang akan dilakukan dalam menganalisi data, mulai dari mengolah data untuk di analisis, merefleksikan kesuluruhan data, coding data, sampai kepada interpretasi data (Creswell, 2019). Analisis data yang dilakukan oleh peneliti untuk mendapatkan informasi tentang proses pengalaman remaja broken home mulai dari pra-broken home, saat broken home dan pasca-broken home dengan berlandaskan teori kedukaan serta bimbingan-bimbingan yang didapatkan oleh remaja broken home.

\section{HASIL TEMUAN}

Subjek dalam penelitian ini kemudian disebut dengan inisial MP. MP lahir di sebuah desa yang sangat terpencil, tepatnya di Yogyakarta. MP merupakan anak pertama dari dua bersaudara. Sebagai anak sulung, segala keinginan MP selalu dituruti oleh orang tuanya yang membuat ia menjadi anak yang manja. kasih sayang orang tua yang didapatkan oleh MP bisa dikatakan maksimal. Hal ini tergambarkan dari setiap kebutuhan MP selalu terpenuhi. Berbeda dengan adiknya yang hampir dari setengah umurnya di asuh oleh kakeknya. Kasih sayang yang didapatkan oleh MP dengan adiknya tentu sangatlah berbeda.

\section{Pengalaman Pra-Broken Home}

Memiliki orang tua yang mapan merupakan hal yang sangat dibanggakan 
oleh setiap anak. Sebagaimana yang diungkapkan oleh MP sebagai berikut:

"Waktu lagi jayanya orang tua saya, tidak ada satupun keinginan saya yang tidak dipenuhi. Mulai dari dibeliin HP, PS, bahkan sepeda motor. Secara kan bapak saya bekerja di sebuah hotel mewah berbintang lima dan posisinya pun sebagai assistant manager. Sementara ibuk saya sebagai karyawan di sebuah toko oleh-oleh makanan khas Jogja. Jadi kedua orang tua saya memiliki penghasilan masing-masing, sehingga segala kebutuhan dalam rumah tangga tercukupi. Selama saya tinggal sama orang tua hubungan mereka baik-baik aja, jarang ada masalah apalagi sampai bertengkar. Kalaupun ada masalah, salah satu di antara mereka biasanya bersikap diam seolah-olah tidak mau memperpanjang masalah tersebut."

\section{Pengalaman Saat Broken Home}

Perceraian orang tua adalah akhir dari sebuah masa depan, seperti yang katakan oleh MP:

"Setelah perceraian orang tua, kehidupan saya menjadi berubah drastis. Hampir setiap malam saya menghabiskan waktu untuk mendem (minum alkohol) di club-club malam dan ditemani dengan cewek-cewek bayaran. Bahkan sempat mengkonsumsi narkoba, mungkin dengan narkoba masalah bisa terlupakan dan perasaan menjadi tenang sebagaimana yang dilakukan oleh banyak orang. Hingga pada akhirnya saya memutuskan untuk berhenti kuliah karena hidup sudah hancur, gak jelas seperti ini ditambah sudah tidak ada lagi kesanggupan orang tua untuk membiayai kuliah saya."
Hal ini dikuatkan dengan hasil observasi yang didapatkan oleh peneliti dengan tidak direncanakan bahwa ketika itu MP sedang mendem (minum anggur merah) dengan teman-temannya dari selepas Isya sampai menjelang Subuh di kamar kos MP. Kedepresian hidup yang dialami oleh MP sangat lama, tidak hanya tergambarkan dari setiap perilaku, akan tetapi ucapan-ucapan yang kerap dilontarkan oleh MP juga menggambarkan bahwa ia belum mampu menerima keadaannya, seperti yang pernah dikatakan oleh MP sebagai berikut:

"Kok Tuhan memberikan saya musibah sebesar ini ya, coba kalau saya gak kuliah mungkin orang tua saya gak cerai atau seandainya saya udah nikah mungkin gak sepesimis atau depresi menghadapi masalah keluarga seperti ini. Terkadang tuhan itu gak adil, kenapa harus saya coba? yang ditakdirkan seperti ini. Memang di dunia ini tidak ada orang yang dalam hidupnya selalu bahagia dan tidak ada juga orang yang dalam hidupnya selalu susah. Tapi kalau ujiannya seperti ini saya gak mampu dan tidak bisa menerima itu semua.

\section{Pengalaman Pasca Broken Home}

Sesungguhnya Allah tidak akan akan mengubah nasib seseorang hingga orang itu mau mengubah dirinya sendiri, seperti yang dinyatakan oleh MP berikut ini:

"Kadang-kadangsayamerenung, kok selama ini hati saya tidak pernah tenang menjalani hidup seperti ini. Terbesit dalam benak bahwa ada yang gak beres dengan diri ini. Apa mungkin karena hubungan saya dengan Tuhan 
tidak baik, jarang shalat, bahkan selalu berburuk sangka terhadap takdir Allah. Hingga pada akhirnya saya berfikir bahwa kalau saya kayak gini terus mau jadi apa nantinya. Masa tua pasti akan saya alami dan saya tidak ingin apa yang saya hadapi saat ini, dihadapi juga oleh anak saya nantinya. Saya harus banyak belajar dari orang-orang yang terpinggirkan namun bisa menjadi orang sukses. Pokoknya saya harus berubah dan hidup mandiri dari orang tua. Apa yang Tuhan takdirkan kepada saya saat ini harus saya terima dengan lapang dada, toh juga ini datangnya dari Tuhan pasti ada hikmah di balik ini semua.Menerima kenyataan bukan berarti membuat kita kembali akan merasakan kebahagiaan seperti sebelumnya, melainkan untuk berusaha bangkit dari keterburukan (move on) dan ikhlas menerima keadaan yang ada."

Dikuatkan lagi oleh MP dengan menyatakan:

"Saya gak sama seperti kebanyakan orang kalau lagi depresi atau frustasi. Teman saya kuliah dulu pernah cerita kalo dia hampir mau bunuh bapaknya karena keluarga mereka kandas disebabkan adanya perselingkuhan dari bapaknya sendiri. Mungkin mas ozi juga sering liat di berita, orang depresi atau korban perceraian orang tua kerap melakukan tindakan kriminal di jalanan maupun lingkungan sekitarnya. Tapi kalau saya gak separah mereka mas, sempat sih ingin melakukan hal demikian tapi saya mikir gini mas seandainya saya kayak gitu apa manfaatnya coba buat diri saya malah akan menambah masalah. Jadi saya hanya melampiasakan rasa frustasi atau kedepresian saya dengan cara ngajak teman-teman mendem (minum alkohol) atau pergi ke tempat hiburan malam.

Ucapan MP tersebut terbukti bahwa sekarang ini ia tinggal di kos-kosan, hidup mandiri tanpa kasih sayang orang tua lagi. Saat ini juga MP bekerja sebagai tukang ojek online (Gojek) yang setiap harinya mendapatkan penghasilan minimal seratus lima puluh ribu rupiah. Dengan memiliki penghasilan yang lumayan banyak setiap harinya membuat kebutuhannya tercukupi. Terlihat bahwa ada perubahan yang dialami oleh MP dalam dirinya, sebagaimana yang dinyatakan bahwa:

"Hidup itu hanya sekali dan kita di dunia hanyalah sesaat. Jadi untuk apa selalu menyesali dan meratapi apa yang telah terjadi. Meskipun tanpa support orang tua, tapi saya bersyukur ada sosok wanita yang menerima keadaan saya apa adanya dan dia yang selalu mensupport dan memberikan semangat untuk menjalani hari-hari demi meraih cita-cita yang saya inginkan. Masa lalu adalah sesuatu yang telah hilang dan tidak akan kembali lagi, masa sekarang adalah milik saya, jadi saya harus berusaha semaksimal mungkin, dan esok adalah suram kita tidak tau apa yang akan terjadi. Kita hanya bisa merencanakan tapi Tuhan yang akan menentukan."

\section{PEMBAHASAN}

\section{Proses Tahapan Kedukaan (Grieving)}

Penelitian ini mengkaji proses yang dialami oleh remaja broken home melalaui proses grieving (Ross, 2009). Berdasarkan hasil penelitian dari data yang telah di analisis, dapat diketahi bahwa ada lima tahap dalam proses kedukaan ini yakni tahap denial, anger, bergaining, depression, dan acceptance.

\section{Fase Denial (Penolakan)}

Untuk sampai kepada proses menuju penerimaan diri, maka hal pertama 
yang akan dialamai oleh orang yang yang sedang berduka, dalam hal ini remaja yang broken home adalah tahap denial, yaitu sikap penolakan terhadap sesuatu yang sedang dihadapi. Dalam tahap ini, subyek menolak perceraian orang tuanya. Penolakan yang dialami oleh anak merupakan mekanisme pertahanan yang bersifat alami sehingga wajar terjadi (Ross, 2009). Perceraian orang tua berdampak pada mental anak, seperti trauma, depresi dan mengasingkan diri dari lingkungan (Ningrum, 2013), bahkan terhadap perkembangan psikososial dan prestasi belajar (Mone, 2019). Sehingga yang kerap menjadi korban dari perceraian orang tua adalah anak itu sendiri. Kendati orang tua berfikir bahwa dengan bercerai maka jalan terbaik bagi keduanya, akan tetapi tidak bagi anak (Asriandari, 2015). Remaja mengalami tekanan antara ketergantungannya terhadap orang tua dan kebutuhan untuk menjadi individu yang mandiri. Orang tua pun sering memiliki perasaan yang bercampur aduk dalam diri, mereka menginginkan anakanaknya untuk menjadi mandiri tetapi mereka menyadari bahwa sulit untuk dapat melepas anak mereka menjadi mandiri (Fadilah, 2018) namun hal tersebut tidak akan dialami oleh anak broken home karena mereka tidak akan mendapatkan lagi bimbingan dan arahan dari orangtuanya sehingga mereka akan menjadi mandiri tanpa pengontrolan.

\section{Fase Anger (Marah)}

Jika sikap penolakan tidak dapat dipertahankan lagi, maka fase pertama berubah menjadi kemarahan (anger). Perilaku individu secara karakteristik dikaitkan dengan marah dan rasa bersalah (Ross, 2009). Terdapat dua bentuk kemarahan yang dialami oleh remaja broken home, yakni kemarahan internal dan eksternal. Kemarahan secara internal titunjukkan oleh subyek kepada diri sendiri menunjukkan bahwa dirinya merasa lemah dan tidak berharga. Sedangkan kemarahan secara eksternal ditunjukkan oleh subyek kepada orangtuanya bahwa penyebab perceraian mereka tidak diketahui terkabih dahulu oleh anaknya. Perubahan sikap akan terjadi pada anak korban perceraian orang tua, seperti, merasa rendah diri, sedih, dan marah (Rusdi et al., 2018), suka melamun, sering menangis, sulit berinteraksi dengan temannya, bahkan berfikir bahwa hilangnya kasih sayang orangtua (Purwanti et al., 2013). Tidak hanya itu, korban remaja broken home juga memiliki perasaan kecewa, tertekan, bahkan sakit hati terhadap orang tua sendiri (Arthasari, 2010).

\section{Fase Bergaining (Tawar-Menawar)}

Pada tahap tawar-menawar (bergaining), remaja dengan status keluarga broken home, cenderung mengembangkan pemikiran-pemikiran irasional untuk mengatur kebutuhan dirinya yang belum mampu menerima perceraian orang tuanya. Pada tahap ini dilakukan negosiasi atas status anak broken home (Ross, 2009). Adapun bentuk pemikiran irasional yang ditunjukkan oleh subyek yakni: penyesalan kenapa kuliah serta penyesalah kenapa subyek tidak menikah lebih dini. Pikiran yang positif akan menghilangkan prasangka-prasangka yang tidak jelas (Ida Alfiana, 2018). 


\section{Fase Depression (Depresi)}

Kemudian yang menjadi puncak sikap negatif yang harus dilalui oleh seseorang untuk sampai kepada tahap proses penerimaan diri adalah depresi, yaitu sikap mental negatif yang berdampak pada perasaan, pikiran, tindakan, dan mental kejiwaan seseorang (Ross, 2009). Dalam tahap ini, subjek mengalami depresi. Adapun bentuk sikap depresi yang dialami oleh subjek, seperti sering mengonsumsi minuman keras, berkunjung ke $c l u b-c l u b$ malam, serta mengasingkan diri. Perceraian orang tua tidak hanya berdampak terhadap suami-sitri, akan tetapi berdampak juga terhadap psikis anak (Untari et al., 2018). Akibatnya, anak cenderung melakukan hal-hal negatif yang tidak bisa dikendalikan, seperti sering merokok dan mengonsumsi minuman keras (Irawan et al., 2020), yang pada akhirnya akan merusak organ tubuhnya sendiri (Ningrum, 2013).

\section{Fase Acceptance (Penerimaan)}

Tahap akhir dari proses ini adalah penerimaan, yaitu peneriman diri terhadap masalah yang telah dihadapi. Dalam tahap ini, subyek menerima dirinya sendiri sebagai anak korban perceraian orang tua. Adapun bentuk sikap penerimaan diri yang dialami oleh subyek adalah pikiran positif terhadap suatu masalah bahwa pasti ada hikmah dari setiap ujuan atau cobaan serta adanya dukungan dan ketersediaan dari sang kekasih. Anak yang mampu memahami dan menerima masalah yang terjadi pada keluarganya akan membuat anak menjadi tidak pesimis, selalu meratapi kesedihannya (Wulandri \&
Fauziah, 2019). Semakin tinggi sikap penerimaan diri pada remaja, maka semakin tinggi juga harga diri remaja korban perceraian orang tua (Barbara D.R. Wangge \& Nurul Hartini, 2013). Tahap remaja awal wujud self acceptance dominan berbentuk sikap, sedangkan tahap remaja akhir wujud self acceptance dominan berbentuk perenungan (Dewi Ida Ayu Shintya \& Kartika, 2018).

Subjek dalam penelitian ini mengalami putus kuliah disebabkan hilangnya dukungan orang tua yang sudah tidak sanggup lagi untuk mencukupi kebutuhan biaya kuliah anak. Namun Terkait dengan hal tersebut, maka perlu adanya bantuan dari konselor untuk memberikan bimbingan terhadap permasalahan yang ada dalam keluarga khususnya pada diri anak (Nurfadhilla, 2020). Adapun strategi yang dilakukan dalam rangka mengatasi permasalahan tersebut adalah dengan menggunakan konseling keluarga, yaitu interaksi antara anak dengan orang tua (A. Sari, 2016). Agar tidak ada kesalah pahaman anak terhadap keputusan orang tua yang akan menjadi penyebab anak melakukan perilaku-perilaku negatif. Tidak hanya konseling keluarga, konseling individu juga dibutuhkan dalam hal kasus ini. Layanan konseling individu dilakukan kepada anak terkait dengan problem minimnya perhatian, kasih sayang ibu dan bapak disebabkan kesibukan mereka bekerja untuk memenuhi kebutuhan hidup sehari-hari (Hasanah et al., 2017). 


\section{SIMPULAN}

Penelitian ini menunjukkan bahwa remaja broken home mengalami proses yang sangat Panjang, namun pada akhirnya mampu survive dan menerima keadannya sendiri setelah berhasil mengontrol dirinya sendiri.Adapun proses penerimaan diri remaja broken home melalui beberapa tahap, yaitu 1) tahap Denial, dalam tahap ini remaja menolak keputusan orang tuanya yang bercerai. 2) tahap Anger, dalam tahap ini remaja merasa marah terhadap orang tuanya. 3) tahap Bargaining, dalam tahap ini remaja memiliki sikap negosiasi terhadap diri sendiri dengan mengatakan seandainya saya tidak kuliah mungkin orang tua tidak cerai. 4) tahap Depression, dalam tahap ini remaja merasa pesimis dan putus asa dengan melakukan perilaku-perilaku negatif seperti mengonsumsi alkohol, berkunjung ke clu-club malam, dan mengasingkan diri pada waktu-waktu tertentu. 5) tahap Acceptance, dalam tahap ini remaja menerima dirinya sendiri. Adapun bimbingan yang dipatkan untuk bisa kembali menerima dirinya adalah melalui bimbingan keluarga.

\section{DAFTAR PUSTAKA}

A. Sari. (2016). Konseling Keluarga Untuk Mencegah Perceraian. EDUCATION, 2(1).

Arthasari. (2010). Perbedaan Antara Forgiveness Dengan Kepribadian Big Five Factors Pada Remaja Korban Perceraian Di Bumi Serpong Damai Tangerang. UIN Syarif Hidayatullah Jakarta.

Asriandari, E. (2015). Resiliensi remaja korban perceraian orangtua. Jurnal Bimbingan Dan Konseling, 9(4), 1-11.

Aziz, M. (2015). Perilaku sosial anak remaja korban broken home dalam berbagai perspektif. Jurnal AlIjtimaiyyah, 1(1), 30-50.

Barbara D.R. Wangge, \& Nurul Hartini. (2013). Hubungan antara Penerimaan Diri dengan Harga Diri pada Remaja pasca Perceraian Orangtua. Jurnal Psikologi Kepribadian Dan Sosial, 2(1), 1-6.

Batubara, J. R. (2016). Adolescent Development (Perkembangan Remaja). Sari Pediatri, 12(1), 21.

Dewi Ida Ayu Shintya, \& Kartika, H. Y. (2018). Dinamika Penerimaan Diri Pada Remaja Broken Home Di Bali Ida Ayu Shintya Dewi dan Yohanes Kartika Herdiyanto. Jurnal Psikologi Udayana, 5(2), 434-443.

Fallis, A. (2017). Bimbingan Konseling Keluarga Dan Remaja. In uin sunan ampel presss anggota IKAPI.

Hadyani, I. A., \& Indriana, Y. (2017). Proses Penerimaan Diri Terhadap Perceraian Orangtua" The Process of Self Acceptance of Parental Divorce (Sebuah Studi Kualitatif dengan Pendekatan Interpretative Phenomenological Analysis). Empati: Jurnal Karya Ilmiah S1 Undip, 6(3), 303-312.

Hafiza, S., \& Mawarpury, M. (2018). Pemaknaan Kebahagiaan oleh Remaja Broken Home. Psympathic: Jurnal Ilmiah Psikologi, 5(1), 59-66. https://doi.org/10.15575/psy.v5i1.1956

Hasanah, S., Sahara, E., Sari, I. P., 
Wulandari, S., \& Pardumoan, K. (2017). Broken Home pada Remaja dan Peran Konselor. JRTI (Jurnal Riset Tindakan Indonesia), 2(2), 1-6.

Ida Alfiana. (2018). Penerimaan Diri Remaja Keluarga Broken Home Di Balai Pelayanan Sosial Asuhan Anak Budhi Sakti Banyumas. Institut Agama Islam Negeri Purwokerto.

Iis Islami Kartini, Tiara N Listiawaty, \& Tita Rosita. (2019). Gambaran Motivasi Belajar Siswa Yang Mengalami Broken Home (Studi kasus pada enam siswa kelas VII di SMP N 1 arjasari yang mengalami broken home). FOKUS, 1(7), 9-16.

Irawan, R. R., Asrina, A., Kesehatan, P., Masyarakat, I. K., Masyarakat, F. K., \& Muslim, U. (2020). Pembentukan Konsep Diri Remaja ( Studi Pada Remaja Korban Perceraian Orang Tua) Kota Makassar Tahun 2020 Article history. 01(02), 48-58.

Jhon M. Chamberlain, \& David A. F. Haaga. (2001). Unconditional SelfAcceptance and Psychological Health. Journal of Rational-Emotif $\mathcal{E}$ Cognitive-Behavior Therapy, 19(3), 163177.

Jhon W. Creswell. (2019). RESEARCH DESIGN Pendekatan Metode Kualitatif, Kuantitatif, dan Campuran (ke-IV). Pustaka Pelajar.

King A. Laura. (2013). The Science of Pshycology: An Appreciative View (Brian Marwendsy (ed.)). Salemba Humanika.

Mone, H. F. (2019). Dampak perceraian orang tua terhadap perkembangan psikososial dan prestasi belajar. Harmoni Sosial: Jurnal Pendidikan IPS, 6(2), 155-163.

Ningrum, P. R. (2013). Perceraian Orang Tua dan Penyesuaian Diri Remaja (Studi pada Remaja Sekolah Menengah Atas/Kejuruan di Kota Samarinda). EJournal Psikologi, 1(1), 69-79.

Nurfadhilla, N. (2020). Upaya Meningkatkan Efikasi Diri Melalui Layanan Bimbingan Konseling. ENLIGHTEN: Jurnal Bimbingan Konseling Islam, 3(1), 48-59. https://doi.org/10.32505/enlighten.v3i 1.1495

Pratama, R., Syahniar, S., \& Karneli, Y. (2016). Perilaku Agresif Siswa dari Keluarga Broken Home. Konselor, 5(4), 238-246.

Purwanti, D., Ropi, H., \& Efri Widianti. (2013). Gambaran respon berduka pada anak remaja dengan orangtua bercerai di SMP Negeri 1 Jatinangor Kabupaten Sumedang. Jurnal Keperawatan Jiwa, 1(2), 135-147.

Putri, I. A. K., \& Tobing, D. H. (2016). Gambaran Penerimaan Diri pada Perempuan Bali Pengidap HIV-AIDS. Jurnal Psikologi Udayana Program Studi Psikologi, 3(3), 395-406.

Putro, Khamim Zarkasih. (2017). Memahami Ciri dan Tugas Perkembangan Masa Remaja. APLIKASIA: Jurnal Aplikasi Ilmu-Ilmu Agama, 17(1), 25-31

Rahmawati, P. A. (2015). Hubungan antara Kepercayaan dan Keterbukaan Diri terhadap Orang Tua dengan Perilaku 
Memaafkan pada Remaja yang Mengalami Keluarga Broken Home di SMKN 3 \& SMKN 5 Samarinda. EJournal Psikologi, 3(1), 395-406.

Ross, K. (2009). On death and dying: what the dying have to teach doctors, nurses, clergy and their own families. Routledge.

Rusdi, Edy Mulyono, Sheela Christina, \& Linda Dwi Novial Fitri. (2018). Studi Fenomenologi Respon Berduka Akibat Perceraian Orang Tua Pada Remaja Di SMPN 5 Jahab Tenggarong Kutai Kartanegara. An-Nada, 95-100.

S Willis. (2009). Konseling Keluarga (Family Counselling). Alfa Beta.

Safitri, A. M. (2017). Proses dan Faktor yang Mempengaruhi Perilaku Memaafkan pada Remaja Broken Home. Psikoborneo, 5(1), 152-161.

Sarlito Sarwono. (2013). Paikologi Remaja. Raja Grafindo Persada.

Triyono, T. (2020). Kontribusi Sikap Orang Tua terhadap Kemandirian Anak. ENLIGHTEN: Jurnal Bimbingan Konseling Islam, 3(1), 26-34. https://doi.org/10.32505/enlighten.v3i 1.1569

Untari, I., Putri, K. P. D., \& Hafiduddin, M. (2018). Dampak Perceraian Orang
Tua Terhadap Kesehatan Psikologis Remaja. Profesi (Profesional Islam): Media Publikasi Penelitian, 15(2), 99106.

Victor Omoruyi, I. (2014). Influence of Broken Homes on Academic Performance and Personality Development of the Adolescents in Lagos State Metropolis. European Journal of Educational and Development Psychology, 2(2), 10-23.

Wulan Dwiyanti Rahayu, \& Mila Fatimah. (2019). Gambaran Konsep Diri Siswi Yang Mengalami Broken Home (Studi Kasus pada 2 Siswi SMK Bunga Persada Cianjur yang Mengalami Broken Home). FOKUS, 2(3), 37-42.

Wulandri, D., \& Fauziah, N. (2019). Pengalaman Remaja Korban Broken Home (Studi Kualitatif Fenomenologis). Empati, 8(1), 1-9.

Yunita, A., \& Lestari, M. D. (2018). Proses Grieving Dan Penerimaan Diri Pada Ibu Rumah Tangga Berstatus Hiv Positif Yang Tertular Melalui Suaminya. Jurnal Psikologi Udayana, 4(02), 222-237. 